Revista Brasil. Bot., V.32, n.3, p.499-508, jul.-set. 2009

\title{
Microsatellite-dense genetic map: towards genome coverage in a tropical maize (Zea mays L.) population'
}

\author{
MILENA DE LUNA ALVES LIMA ${ }^{2,5}$, CLÁUDIO LOPES DE SOUZA JR. ${ }^{3}$ and \\ ANETE PEREIRA DE SOUZA ${ }^{4}$
}

(received: February 15, 2007; accepted: April 29, 2009)

\begin{abstract}
Microsatellite-dense genetic map: towards genome coverage in a tropical maize (Zea mays L.) population). Dense molecular genetic maps are used for an efficient quantitative trait loci (QTL) mapping and in the marker-assisted selection programs. A dense genetic map was generated with 139 microsatellite markers using $256 \mathrm{~F}_{2}$ plants generated by the crossing of two tropical maize inbred lines (L-02-03D and L-20-01F). This map presented 1,858.61 cM in length, where 10 linkage groups were found spanned, with an average interval of $13.47 \mathrm{cM}$ between adjacent markers. Seventy seven percent of the maize genetic mapping bins were covered, which means an increase of $14 \%$ coverage in relation to the previous tropical maize maps. The results provide a more detailed and informative genetic map in a tropical maize population representing the first step to make possible the studies of genetic architecture to identify and map QTL and estimate their effects on the variation of quantitative traits, thus allowing the manipulation and use in tropical maize breeding programs.
\end{abstract}

Key words - dense genetic map, genome coverage, microsatellites, tropical maize, Zea mays L.

RESUMO - (Mapa genético saturado de microssatélite: caminhando para uma cobertura genômica em uma população de milho tropical (Zea mays L.). Mapas genéticos saturados são utilizados para um eficiente mapeamento de caracteres de interesse agronômico (QTL) e nos programas de seleção assistida. Este trabalho gerou um mapa genético saturado utilizando 139 marcadores moleculares do tipo microssatélites em 256 plantas $\mathrm{F}_{2}$ geradas pelo cruzamento de duas linhagens de milho tropical (L-02-03D e L-20-01F). O mapa obtido teve uma extensão total de 1.858,61 cM, ao longo de 10 grupos de ligação, com intervalo médio entre os marcadores de 13,47 cM. Setenta e nove percento dos "bins" do mapa genético de milho foram cobertos, com um acréscimo de $14 \%$ de cobertura em relação aos mapas de milho publicados. Os resultados mostram um mapa genético mais detalhado e informativo em uma população de milho tropical representando uma primeira etapa que possibilitará desenvolver estudos da arquitetura genética para a identificação e mapeamento de QTL e a estimativa de seus efeitos sobre a variação de um caráter quantitativo, permitindo assim a sua manipulação e utilização em programas de melhoramento do milho.

Palavras-chave - cobertura genômica, mapa genético saturado, microssatélites, milho tropical, Zea mays L.

\section{Introduction}

The use of a highly dense molecular genetic map using informative markers is very important for efficient QTL mapping for potential applications in markerassisted selection and introgression programs capable of increasing breeding efficiency and to overcome some limitations of conventional breeding methods (Young 1999). Thus, the accuracy of QTL analysis is related to

1. Parte da tese de doutorado da primeira autora, Programa de PósGraduação em Genética e Biologia Molecular da Universidade Estadual de Campinas, São Paulo.

2. Universidade Federal do Paraná, Setor de Ciências Agrárias, Curso de Engenharia Florestal, Av. Prof. Lothário Meissner, 900, Jardim Botânico, 80210-170 Curitiba, PR, Brazil.

3. Universidade de São Paulo, Escola Superior de Agricultura Luiz de Queiroz, Departamento de Genética, Caixa Postal 83, 13400-970 Piracicaba, SP, Brazil.

4. Universidade Estadual de Campinas, Instituto de Biologia, Centro de Biologia Molecular e Engenharia Genética, Caixa Postal 6010, 13083-970 Campinas, SP, Brazil.

5._Corresponding author: milenal@hotmail.com the occurrence of a linking between molecular marker genotypes and phenotypic values of individuals or lines, which allows the detection and location of the loci that affect quantitative traits (Dekkers \& Hospital 2002). Simulations show that for accurate QTL location, a large population with linkage disequilibrium and a high number of informative markers, with a maximum distance of $5 \mathrm{cM}$ between a marker and the QTL should be used (Moreau et al. 1998).

Several dense molecular genetic maps were developed in the last few years for economically important plant species (Falque et al. 2005, Sargent et al. 2006, Wang et al. 2006, Truco et al. 2007, Varshney et al. 2007). These dense maps facilitate the positional cloning of important genes, allow genetic dissection of quantitative trait loci, and provide an ordered scaffold on which complete physical maps can be assembled. The usefulness of genetic maps thus largely depends on their density (Meksem et al. 2001, Servin \& Hospital 2002).

Many genetic maps have been reported for temperate maize (Zea mays L.) germplasm (Lee et al. 
2002, Sharopova et al. 2002, Wei et al. 2004, Falque et al. 2005). Most of these maps were largely developed to map QTL using $\mathrm{F}_{2}$, immortalized $\mathrm{F}_{2}, \mathrm{BC}_{1}$, double haploid (DH) and recombinant line (RIL) populations (Edwards et al. 1992, Ajmone-Marsan et al. 1995, Austin \& Lee 1996, Veldboom \& Lee 1996, Davis et al. 1999). Few genetic maps are available involving different populations of tropical maize germplasm. Ribault et al. (1996) developed a RFLP genetic map for QTL mapping and used a crossing from two inbred lines derived from Mexican races of maize for the lowland tropics (Tuxpeñobased germplasm). Sibov et al. (2003) and Mangolin et al. (2004) constructed microsatellite-genetic maps in tropical maize populations derived from Brazilian and Mexican germplasm, however both of the genetic maps presented some genomic regions with large distances between markers that might be reducing the number of QTL mapped. Currently, no molecular dense genetic map has been published for tropical maize population.

Despite the proven efficiency of the use of RFLP marker in the development of genetic maps, this methodology very costly in time and money, also not providing a balanced coverage of the genome in some cases, which is an important requirement for efficient QTL mapping. The use of the microsatellites, or SSR (Simple Sequence Repeats), as molecular markers helps mapping studies due to the quick and easy data obtention, which allows the automation of the methodology in laboratory. The advantage of using these markers is that they are specific loci, multiallelic and highly polymorphic. Besides, microsatellites are codominant genetic markers with Mendelian inheritance, like the RFLP, and are distributed randomly in the genomes of many eukaryotes (Ellegren 2000, Schlötterer 2004).

Several authors developed microsatellites using a temperate maize germplasm, which is available in the Maize Genetics and Genomics Database (MaizeGDB - http://www.maizegdb.org/ssr.php). In this website all the information on these markers is available, such as the primer sequences, the locus designation, the description of microsatellite motifs, the size of the PCR product amplified in reference lines, and the chromosome location based on "bin boundaries" (Gardiner et al. 1993).

In this context, the objective of this study was to reach greater genome coverage to obtain a dense genetic map of an $F_{2}$ population of tropical maize from two contrasting inbred lines, to use molecular markers microsatellite developed from temperate maize populations, and also determine the efficiency and the level of polymorphism of the those markers. Only a highresolution and marker-dense genetic map will provide a better understanding of genetic architecture for future QTL mapping studies that can be used in the tropical maize breeding programs.

\section{Materials and methods}

Genetic materials - The plant material used in this study has already been described in detail (Mangolin et al. 2004). Briefly, the parental inbred lines L-20-01F and L-02-03D were derived from the Brazilian early-flowering maize populations IG-1 (orange flint kernels) and IG-2 (yellow dent kernels), respectively. These populations and their respective inbred lines were in different heterotic groups and they were developed by the Maize Breeding Program of the Department of Genetics (ESALQ - Universidade de São Paulo). Both populations were derived only from tropical germplasm. The inbred lines were crossed deriving the $F_{1}$ plants which were self-pollinated to generate the $256 \mathrm{~F}_{2}$ plants. Three $\mathrm{F}_{1}$ plants were previously screened against the inbred parental lines with microsatellite markers to access their genetic identity, in order to discard $\mathrm{F}_{1}$ plants produced with pollen from other genotype.

Microsatellite genotyping - Young leaves from $F_{1}, F_{2}$ and parental lines were collected, freeze-dried and ground. The material was stored at $-20{ }^{\circ} \mathrm{C}$ in individually labeled vials. DNA extraction followed the procedure which uses CTAB described by Hoisington et al. (1994). The amplification conditions followed the process described by Sibov et al. (2003), who adopted two amplification programs: the Touchdown PCR (Don et al. 1991) and the one that uses specific annealing temperature (TA), calculated by the Marmur \& Doty (1962) formula. All amplifications were carried out using a PTC-100 thermalcycler (MJ Research, Inc.). PCR products were separated in either $0.5 \cdot \mathrm{TBE}$ buffer (Sambrook et al. 1989), high-resolution agarose gel (agarose/MetaPhor $1: 1), 6 \%$ polyacrylamide gels, based on the genotyping difficulty of each microsatellite. Horizontal electrophoresis was conducted at $170 \mathrm{~V}$ for 1,5 hours in HORIZON 20:25 gel system (GIBCO BRL) and stained with ethidium bromide $\left(0.5 \mu \mathrm{g} \mathrm{mL}^{-1}\right)$ for 0,33 hours. For the documentation and analyses of the gel, the equipment GeneGenius (Syngene Ltda.) was used. Vertical electrophoresis were conducted at $90 \mathrm{~W}$ for 2,0 h using a Model S2001 Sequencing Gel Electrophoresis Apparatus (Life Technologies - GIBCO BRL), and samples were detected by silver staining according to Creste et al. (2001).

Microsatellite primer selection - In order to fill the regions still not covered in the map developed by Mangolin et al. (2004) that used the same mapping population, 392 microsatellite primers were choosen and synthesized by Invitrogen ${ }^{\mathrm{TM}}$. From those, 72 microsatellites were polymorphic based on the existing allelic polymorphism between the parental and the segregating population and these were selected for the work. All information regarding primers used can be 
found in MaizeGDB (http://www.maizegdb.org/ssr.php). From the 72 selected microsatellites 8 were later discarded due to problems that occurred during the genotyping of the population, resulting in a 64 microsatellites base which the main information are described in table 1 .

Genetic map - Sixty-four microssatélites were grouped with the 75 microsatellites obtained from Mangolin et al. (2004), resulting in a 139 base, and used to develop the dense genetic map in tropical maize population. Each marker locus was checked for deviation from the expected Mendelian segregation ratio $(1: 2: 1)$ by standard $\chi^{2}$ analysis $(P<0.05$ and $P<0.01)$. Because multiple tests were performed, appropriate type I error rates were determined by the sequentially rejective Bonferroni procedure (Rice 1989). The dense genetic map was constructed based on linkage analyses using the MAPMAKER/EXP version 3.0b program (Lincoln et al. 1993). Linkage was inferred using a LOD $(\log 10$ of the odds ratio) threshold of 3.0 and maximum distance between two loci of $50 \mathrm{cM}$ for forming linkage groups. Two-point linkage analysis was conducted to estimate the maximum likelihood recombination frequency and linkage groups were established with the "group" command. The Kosambi (1944) mapping function was used to convert recombination frequencies into map distances (cM). Linkage analyses were then conducted to determine the most likely order of loci within groups using the "compare" command for all groups and the likelihood of all possible orders were compared. Once the most likely order of the subset is chosen, the remaining marks were inserted by means of a "try" command. The consistency of the orders was verified by means of a "ripple" command determined by multipoint analyses. The linkage groups with markers distances higher than $50 \mathrm{cM}(\mathrm{r}=0.38)$ were grouped using the previous information of the microsatellite location (bin) on the maize chromosomes, which is available in the MaizeGDB. This procedure was also used by Sibov et al. (2003) and Mangolin et al. (2004), and it allowed a graphic representation of the map.

Table 1. Primers selected and used in the tropical maize map.

\begin{tabular}{|c|c|c|c|c|c|}
\hline № & $\operatorname{Bin}^{\mathrm{a}}$ & $\begin{array}{c}\text { Locus } \\
\text { designation }\end{array}$ & $\begin{array}{l}\text { Microsatellite } \\
\text { motifs }^{c}\end{array}$ & Primers sequence: forward (left end) / reverse (right end) & $\begin{array}{l}\text { Amplification } \\
\text { conditions }^{\mathrm{d}}\end{array}$ \\
\hline 1 & 1.02 & bnlg1007 & $(\mathrm{AG}) 15$ & GATGCAATAAAGGTTGCCGT / ATGTGCTGTGCCTGCCTC & $\mathrm{TA}\left(55^{\circ} \mathrm{C}\right)$ \\
\hline 2 & 1.02 & bnlg1178 & $(\mathrm{AG}) 16$ & ACTACAGTTGAACGCCCCTG / GCTCATGTGCAAATGCAAGT & $\mathrm{TA}\left(55^{\circ} \mathrm{C}\right)$ \\
\hline 3 & 1.03 & bnlg1203 & $(\mathrm{AG}) 17$ & GACCCGTCTCTCTTGAGTGC / GTCTGTCTGCACCCGTTTTT & TD \\
\hline 4 & 1.03 & bnlg1953 & $(\mathrm{AG}) 17$ & CCTCGGAGCTCGATTTACAC / AACATTTAACCGCCGTCATC & TD \\
\hline 5 & 1.04 & umc1558 & $(\mathrm{AG}) 7$ & GAGGTTGAGAGCAGCATATGAAAAA / AAGGTGGAGAACCAGAAGAGGAAG & $\mathrm{TD}$ \\
\hline 6 & 1.04 & umc1917 & (CTG)6 & ACTTCCACTTCACCAGCCTTTTC / GGAAAGAAGAGCCGCTTGGT & $\mathrm{TA}\left(54^{\circ} \mathrm{C}\right)$ \\
\hline 7 & 1.05 & umc2025 & $(\mathrm{AGCT}) 4$ & CGCCGTAGTATTTGGTAGCAGAAG / TCTACCGCTCCTTCGTCCAGTA & $\mathrm{TA}\left(55^{\circ} \mathrm{C}\right)$ \\
\hline 8 & 1.06 & umc1919 & (CT) 8 & TAAATCTGAGCCAGTCATAAGGGC / AGCAGAATAAAGTACGGTAGAGGTGG & $\mathrm{TA}\left(60^{\circ} \mathrm{C}\right)$ \\
\hline 9 & 1.10 & umc1737 & $(\mathrm{AGA}) 7$ & ATGCTTCTCTTCAGAAGCCATCC / TAGCTAGGTAGTGATGTGCGTGCT & TD \\
\hline 10 & 1.11 & umc1630 & (ATGGG)4 & CAGACCTTCGAGGGCAAGAACT / AGTTTTGGCTTCTTCTCCCAAGTC & $\mathrm{TA}\left(60^{\circ} \mathrm{C}\right)$ \\
\hline 11 & 1.12 & umc1797 & $(\mathrm{AC}) 20$ & TCAAGTGAAATGCATAGCTTGCTC / ACTGTTGGTAAACCCTGCATGACT & $\mathrm{TA}\left(60^{\circ} \mathrm{C}\right)$ \\
\hline 12 & 2.01 & umc1227 & $(\mathrm{AGG}) 4$ & CAAGTTGGTGAGATGGATCTGTTG / GCTCCTGGGTCTTCCTCTCC & TD \\
\hline 13 & 2.02 & bnlg1017 & $(\mathrm{AG}) 18$ & ATTGGAAGGATCTGCGTGAC / CAGCTGGTGGACTGCATCTA & $\mathrm{TA}\left(55^{\circ} \mathrm{C}\right)$ \\
\hline 14 & 2.02 & umc1542 & $(\mathrm{AG}) 10$ & TAAAGCTATGATGGCACTTGCAGA / CATATTTGCCTTTGCCCTTTTGTA & TD \\
\hline 15 & 2.03 & mmc0111 & $(\mathrm{GA}) 34$ & TACTGGGGATTAGAGCAGAAG / AATCTATGTGTGAACAGCAGC & TD \\
\hline 16 & 2.07 & bnlg2077 & $(\mathrm{AG}) 33$ & GACCAGAGGATGGGGAAATT / GTAGGCACATGCACATGAGG & TD \\
\hline 17 & 2.07 & umc1042 & $(\mathrm{GA}) 17$ & AAGGCACTGCTACTCCTATGGCTA / CTGACCTTTGAATTCTGTGCTCCT & TD \\
\hline 18 & 2.07 & umc1560 & $(\mathrm{GC}) 6$ & CGTTCGTCTCTGGGTAGCGTAG / TATAACAGCCTGCTGCTGCTTG & $\mathrm{TA}\left(54^{\circ} \mathrm{C}\right)$ \\
\hline 19 & 2.07 & umc1946 & (GCTGCT) & GAAACGACCAGCACAGCACAT / GCACCACACCATCAGATCCAG & $\mathrm{TA}\left(55^{\circ} \mathrm{C}\right)$ \\
\hline 20 & 2.08 & bnlg1329 & $(\mathrm{AG}) 14$ & ATAGAATGGGATGTGGGCAA / TCCGATCATATCGGGAGATC & $\mathrm{TA}\left(52^{\circ} \mathrm{C}\right)$ \\
\hline 21 & 2.08 & bnlg1662 & $(\mathrm{AG}) 18$ & GCACCCACATGAAGTATCCC / TTGTTTTTGCAGTGCCTCAG & $\mathrm{TA}\left(52^{\circ} \mathrm{C}\right)$ \\
\hline 22 & 2.08 & bnlg1721 & $(\mathrm{AG}) 23$ & ACGACTTTCATGCCTCGTCT / ATTTCTTTTGCCACCTCAGC & $\mathrm{TA}\left(54^{\circ} \mathrm{C}\right)$ \\
\hline 23 & 2.08 & umc1516 & $(\mathrm{TA}) 12$ & CAATAACAGATCAGCATGGAGACG / TAGCGACCTGTTATCCGAAAGAAC & TD \\
\hline 24 & 3.04 & bnlg1647 & $(\mathrm{AG}) 23$ & CGTCGTCTGTGGACGTACTG / AGAAGCTCACAAGCCTGCTC & $\mathrm{TA}\left(55^{\circ} \mathrm{C}\right)$ \\
\hline
\end{tabular}


continuation

\begin{tabular}{|c|c|c|c|c|c|}
\hline № & $\operatorname{Bin}^{\mathrm{a}}$ & $\begin{array}{c}\text { Locus } \\
\text { designation }\end{array}$ & $\begin{array}{l}\text { Microsatellite } \\
\text { motifs }^{\mathrm{c}}\end{array}$ & Primers sequence: forward (left end) / reverse (right end) & $\begin{array}{l}\text { Amplification } \\
\text { conditions }^{\mathrm{d}}\end{array}$ \\
\hline 25 & 3.04 & bnlg1904 & $(\mathrm{AG}) 21$ & AGGAGCATGCACTTGGTTCT / ACTCAACTGATGGCCGATCT & $\mathrm{TA}\left(55^{\circ} \mathrm{C}\right)$ \\
\hline 26 & 3.04 & umc1025 & $(\mathrm{CT}) 11$ & GCTCCACTTCCACCCTGATATG / CGCTAATGTCCCCATTGATGAT & TD \\
\hline 27 & 3.07 & umc1528 & $(\mathrm{TGCG}) 6$ & AGTTCAACTGCTTAAGATCCGGTG / GTCTGTCGTTGTGTGCCAGTG & TD \\
\hline 28 & 3.07 & umc1659 & $(\mathrm{GA}) 6$ & CAAGCTTGCTACTGTGATTTCTCG / AACTTCTCGGTGATCTTGTCCATC & $\mathrm{TA}\left(60^{\circ} \mathrm{C}\right)$ \\
\hline 29 & 3.09 & bnlg1496 & $(\mathrm{AG}) 18$ & CTGGGCAGACAGCAACAGTA / AGCCAAAGACATGATGGTCC & TD \\
\hline 30 & 3.09 & umc1052 & $(\mathrm{AAC}) 5$ & GTGTACAACACCAGCAACAGCTTC / GTAGCTCCCCATCTTGTCGAAC & $\mathrm{TD}$ \\
\hline 31 & 3.09 & umc1639 & (TGTCC) 4 & CTAGCCAGCCCCCATTCTTC / GCAAGGAGTAGGGAGGACGTG & $\mathrm{TD}$ \\
\hline 32 & 3.10 & umc1641 & (TCGCC) 4 & CTCCCTTCGTCTCCCGACTC/ CAGATCGGCTCAGCCACAAC & $\mathrm{TA}\left(55^{\circ} \mathrm{C}\right)$ \\
\hline 33 & 4.07 & bnlg1189 & $(\mathrm{AG}) 12$ & CGTTACCCATTCCTGCTACG / CTTGCTCGTTTCCATTCCAT & $\mathrm{TA}\left(55^{\circ} \mathrm{C}\right)$ \\
\hline 34 & 4.08 & umc1086 & $(\mathrm{CT}) 12$ & CATGAAAGTTTTCCTGTGCAGATT / GGGCAACTTTAGAGGTCGATTTATT & $\mathrm{TD}$ \\
\hline 35 & 4.09 & umc1939 & NA & CAAATACACCTCCAGCATCAGTTG / GATCCCATTTGTTGTTGCTGCT & $\mathrm{TA}\left(55^{\circ} \mathrm{C}\right)$ \\
\hline 36 & 4.10 & umc1532 & $(\mathrm{AAAT}) 4$ & ATCTAGAAAATTATAATGGCATGGATTC / CTCTCGGTTTTGGACTCTGCT & $\mathrm{TD}$ \\
\hline 37 & 4.10 & umc1738 & $(\mathrm{CGCT}) 5$ & CCAGACATTCCCCAAACCCTA / CGTCGGTGTCGTACTGGTTG & TD \\
\hline 38 & 5.02 & bnlg105 & NA & GACCGCCCGGGACTGTAAGT / AGGAAAGAAGGTGACGCGCTTTTC & $\mathrm{TD}$ \\
\hline 39 & 5.03 & bnlg1208 & $(\mathrm{AG}) 10$ & GCTGTGATGGTGAGACGAGA / GCAGGCACTACTAAAACCGC & $\mathrm{TA}\left(55^{\circ} \mathrm{C}\right)$ \\
\hline 40 & 5.03 & bnlg1660 & $(\mathrm{AG}) 19$ & ACCAAGGTTCTTGGAGGCT / ACCATTGTATTTTCCTAGAGAATCG & $\mathrm{TA}\left(55^{\circ} \mathrm{C}\right)$ \\
\hline 41 & 5.03 & bnlg1879 & $(\mathrm{AG}) 14$ & TGCTCTCACAAGATGGTGGA / CCACAGGATAAAATCGGCTG & $\mathrm{TA}\left(55^{\circ} \mathrm{C}\right)$ \\
\hline 42 & 5.07 & umc2013 & NA & GGGACGAGAGTCTGTTGTTGTTG / GTTGATGCATGTGACTCTGGAAAC & $\mathrm{TA}\left(55^{\circ} \mathrm{C}\right)$ \\
\hline 43 & 5.08 & umc1792 & $(\mathrm{CGG}) 5$ & CATGGGACAGCAAGAGACACAG / ACCTTCATCACCTGCAACTACGAC & TD \\
\hline 44 & 6.00 & bnlg1600 & $(\mathrm{AG}) 21$ & CGATCAGTGCGTGGAGAGTA / TAGGCATGCATTGTCCATTG & $\mathrm{TD}$ \\
\hline 45 & 6.04 & $\operatorname{mmc} 0523$ & (CT)24 & СССТСТCTTCACCСCTT / AGACCCTGCTGCTAGCTAG & $\mathrm{TD}$ \\
\hline 46 & 6.04 & umc2006 & NA & AGTCCATCACCATCCCTGGC / GCAGAACTATTGTCAGTTAACCTTGCAT & $\mathrm{TD}$ \\
\hline 47 & 6.06 & umc1762 & $(\mathrm{TC}) 7$ & CTTACTCCAGGCACTCCATACCAT / ATCCAGGTGAATGGTGTTTACGAT & TD \\
\hline 48 & 6.07 & umc1653 & $($ GAAA) 24 & GAGACATGGCAGACTCACTGACA / GCCGCCCACGTACATCTATC & $\mathrm{TA}\left(60^{\circ} \mathrm{C}\right)$ \\
\hline 49 & 7.01 & umc1066 & $(\mathrm{GCCAGA}) 5$ & ATGGAGCACGTCATCTCAATGG / AGCAGCAGCAACGTCTATGACACT & $\mathrm{TA}\left(52^{\circ} \mathrm{C}\right)$ \\
\hline 50 & 8.08 & umc1069 & $(\mathrm{GGAGA}) 6$ & AGAGAATCCCCAAGCAAACAAAC / CTTCATCGGAGCCATGGTGT & $\mathrm{TA}\left(55^{\circ} \mathrm{C}\right)$ \\
\hline 51 & 9.01 & bnlg1583 & $(\mathrm{AG}) 14$ & ATCAAGCTTATCGAGAGAGAGAGAG / CGACGGTGGAAAGACTGC & $\mathrm{TA}\left(55^{\circ} \mathrm{C}\right)$ \\
\hline 52 & 9.01 & bnlg1810 & $(\mathrm{AG}) 14$ & ATGCTCСТCСТCTCCTCCAT / GCGATGATGAGCTGCAAGTA & $\mathrm{TA}\left(55^{\circ} \mathrm{C}\right)$ \\
\hline 53 & 9.01 & umc1040 & $(\mathrm{CT}) 11$ & CATTCACTCTCTTGCCAACTTGA / AGTAAGAGTGGGATATTCTGGGAGTT & $\mathrm{TA}\left(55^{\circ} \mathrm{C}\right)$ \\
\hline 54 & 9.02 & umc1037 & $(\mathrm{CT}) 16$ & GTGCGCGATTCCTTAGTTTGC / CTTCTTCGTAAAGGCATTTTGTGC & $\mathrm{TD}$ \\
\hline 55 & 9.02 & bnlg1082 & $(\mathrm{AG}) 11$ & AAAGATCATGGGCGTACCAG / CAGGAACCTGATGACCACCT & $\mathrm{TD}$ \\
\hline 56 & 9.02 & bnlg1401 & $(\mathrm{AG}) 22$ & CACTCGGTTTTTGCTTAGCC / GTGTCGTCGAGTGCATGC & TD \\
\hline 57 & 9.07 & bnlg1525 & $(\mathrm{AG}) 25$ & AGGAATTGCGAGTCTTCCAA / CAACCCCCAAAATGAACAAA & $\mathrm{TD}$ \\
\hline 58 & 9.07 & bnlg0279 & NA & GCATGCGTACCTTCAAGCTA / TGTGTTCATCGGCAATTTTG & $\mathrm{TD}$ \\
\hline 59 & 10.05 & umc1827 & $(\mathrm{GAC}) 6$ & GCAAGTCAGGGAGTCCAAGAGAG / CCACCTCACAGGTGTTCTACGAC & $\mathrm{TA}\left(55^{\circ} \mathrm{C}\right)$ \\
\hline 60 & 10.05 & umc2043 & (TCC)4 & GAGGCATACGGCATACCATACC / GTAGGAGAAACAGGTGCTGGTGTC & $\mathrm{TA}\left(55^{\circ} \mathrm{C}\right)$ \\
\hline 61 & 10.06 & umc1993 & $(\mathrm{GCCT})$ & CTTTTCTGCTACTCCTGCCTGC / CTAGCTGATGGAGGCTGTAGCG & $\mathrm{TD}$ \\
\hline 62 & 10.07 & umc1038 & $(\mathrm{CT}) 15$ & CGTCACACTCCTCTGCCACTT / GAGGATTCAGAACTCGACTCGG & $\mathrm{TA}\left(55^{\circ} \mathrm{C}\right)$ \\
\hline 63 & 10.07 & umc2021 & (TGG)4 & AAACTCAAGCTCGGAATGTACTGC / CGATACTGATCTACTTCACGCTGG & $\mathrm{TD}$ \\
\hline 64 & 10.07 & umc1569 & $(\mathrm{GCA}) 4$ & GCAGCTCCAAGTACAGAGGTGAG / CACTGCAGACACGTAAAATCCAAG & $\mathrm{TA}\left(53^{\circ} \mathrm{C}\right)$ \\
\hline
\end{tabular}

\footnotetext{
a Microsatellite location of the maize chromosomes based on the concept of "bins" (Gardiner et al. 1993).

b Microsatellite primers developed in University of Missouri/EUA (umc) and Brookhaven National Laboratory/EUA (bnlg) and available in the MaizeGDB (http://www.maizegdb.org/).

c NA: microsatellite motifs not available in the MaizeGDB (http://www.maizegdb.org/).

d TD: Touchdown PCR amplification program (Don et al. 1991); TA: specific annealing temperature program (Marmur \& Doty 1962).
} 


\section{Results}

Polymorphism analyses - On what regards the allelic polymorphism from the 392 microsatellites tested, $72(18 \%)$ were polymorphic, $255(65 \%)$ were non polymorphic and the remaining $65(17 \%)$ did not amplify, even with annealing temperature optimization (TA). All the polymorphic microsatellites were loci specific, producing just one set of segregating bands.

Forty-four (61\%) polymorphic microsatellites evaluated presented dinucleotide sequence motifs, $12(16 \%)$ showed trinucleotide motifs and six (8\%) displayed tetranucleotide sequence repeats. The most abundant dinucleotide sequence motif found was (AG)n. The best resolution in terms of allele separation was found in the dinucleotide motif during the visualization of the alleles in high-resolution agarose gel. Null alleles, characterized by the non-observation of the allele of one parental inbred line in the $\mathrm{F}_{1}$ generation were observed in $4 \%$ of the $\mathrm{F}_{2}$ plants. These loci were not used in the genetic map.

Genetic map - With the objective of allowing integrated mapping, the maize genome was divided into 100 parts or bins (99 evenly spaced). Each bin was bounded by an RFLP "core marker", with approximately $20 \mathrm{cM}$ each (Gardiner et al. 1993). Based on this concept of bins, Mangolin et al. (2004) map that used the same mapping population obtained a $65 \%$ coverage of the tropical maize genome. In this work a $79 \%$ coverage was obtained presenting a $14 \%$ increase.

According to the first law of Mendel, segregation occurs in a manner wherein a gamete has an equal probability to carry either of the segregating alleles. However, rare deviations from the expected segregation have been known for a long time. These so-called distorters can alter transmission ratio in specific cases (Lyttle 1991). Only one marker displayed segregation distortion in this work which occurred with the umc1516 (bin 2.08) marker, but once not rejected at the $1 \%$ significance level, it was used in the genetic map. The map presented a length of $1,858.61 \mathrm{cM}$ with an average interval of $13.47 \mathrm{cM}$ between markers (figure 1). Ten linkage groups were generated, which were equivalent to 10 maize chromosomes. The linkage group that presented the smallest length was chromosome 10 with $103.62 \mathrm{cM}$, and the greatest was chromosome one with $303.36 \mathrm{cM}$. The length between mapped markers ranged from $0.39 \mathrm{cM}$ (chromosome one) to $103.78 \mathrm{cM}$ (chromosome four). The number of markers in each linkage group ranged from 22 to seven in chromosomes one and seven, respectively. The average number of markers per chromosome was 13.90 with an average distance of $13.47 \mathrm{cM}$ between markers (table 2). Three microsatellites did not link in its respective linkage groups (umc1177, bnlg1370 and phi116), and it is bins data were

Table 2. Results of 10 linkage groups from tropical maize genetic map of $256 \mathrm{~F}_{2}$ plants and their distances in centimorgans (cM).

\begin{tabular}{|c|c|c|c|c|c|c|}
\hline \multirow{2}{*}{$\begin{array}{l}\text { Linkage } \\
\text { group }\end{array}$} & \multirow{2}{*}{$\begin{array}{l}\text { Microsatellite } \\
\text { markers } n^{-}\end{array}$} & \multirow{2}{*}{$\begin{array}{c}\text { Linkage } \\
\text { group distance }\end{array}$} & \multicolumn{3}{|c|}{ Average between microsatellites } & \multirow{2}{*}{$\begin{array}{c}\text { Microsatellites } \\
\text { unlinked* }\end{array}$} \\
\hline & & & $\begin{array}{l}\text { Average } \\
\text { distance }\end{array}$ & $\begin{array}{c}\text { Maximum } \\
\text { distance }\end{array}$ & $\begin{array}{l}\text { Minimum } \\
\text { distance }\end{array}$ & \\
\hline 1 & 22 & 303.36 & 14.45 & 54.08 & 0.59 & umc1177 (1.01) \\
\hline 2 & 19 & 225.64 & 12.54 & 37.66 & 2.57 & \\
\hline 3 & 18 & 245.33 & 14.43 & 40.88 & 0.59 & \\
\hline 4 & 14 & 265.94 & 20.46 & 103.78 & 0.78 & bnlg1370 (4.00) \\
\hline 5 & 13 & 163.43 & 13.62 & 28.46 & 3.38 & \\
\hline 6 & 11 & 136.33 & 13.63 & 27.31 & 3.39 & \\
\hline 7 & 7 & 167.03 & 27.84 & 66.33 & 2.37 & phi116 (7.06) \\
\hline 8 & 10 & 119.02 & 13.22 & 22.52 & 2.38 & \\
\hline 9 & 15 & 128.90 & 9.21 & 36.41 & 1.97 & \\
\hline 10 & 10 & 103.62 & 11.51 & 25.83 & 1.18 & \\
\hline Total & 139 & $1,858.61$ & 13.47 & & & \\
\hline
\end{tabular}

* Denomination of microsatellite loci with their location of based on the concept of "bins" between brackets. 
Chromosome 1

22 markers

$303.36 \mathrm{cM}$

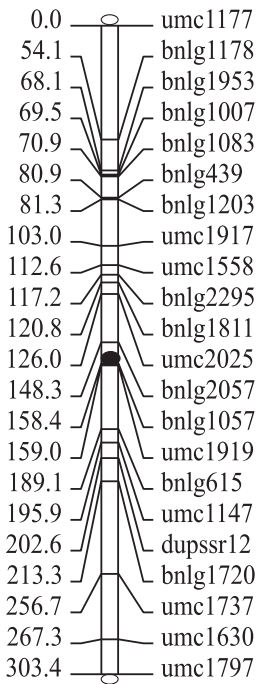

Chromosome 6

11 markers

$136.33 \mathrm{cM}$

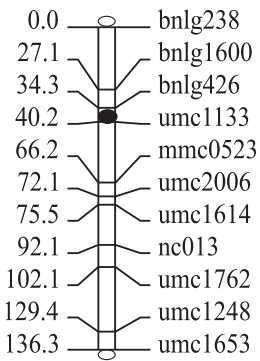

Chromosome 2

19 markers

$225.64 \mathrm{cM}$

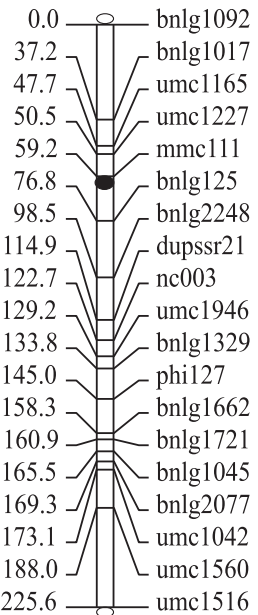

Chromosome 7

7 markers

$167.03 \mathrm{cM}$

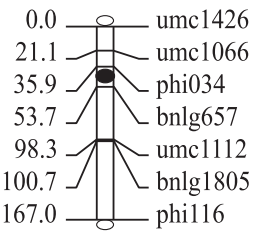

Chromosome 3

18 markers

$245.33 \mathrm{cM}$

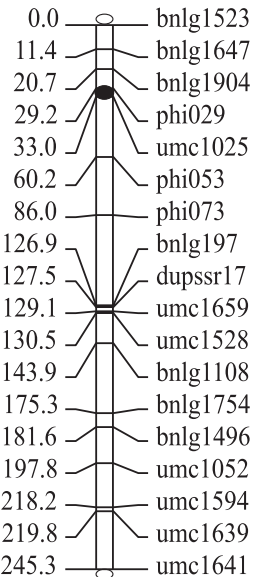

Chromosome 8

10 markers

$119.02 \mathrm{cM}$

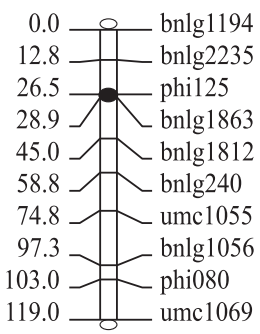

Chromosome 4

14 markers

$265.94 \mathrm{cM}$
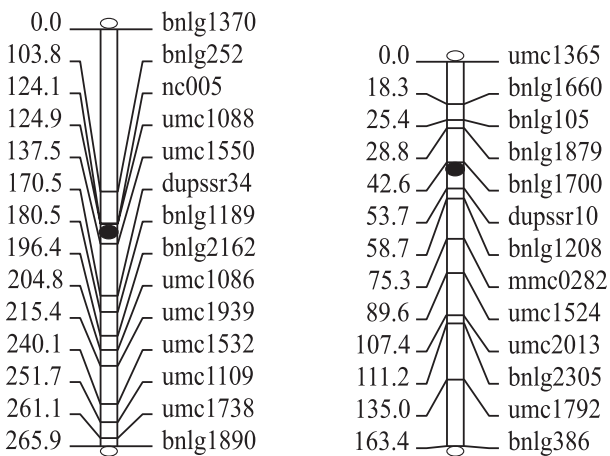

Chromosome 9

15 markers

$128.90 \mathrm{cM}$

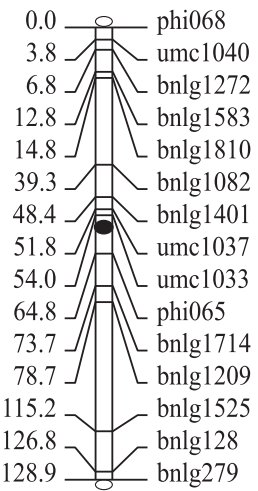

Chromosome 5

13 markers

$163.43 \mathrm{cM}$

Figure 1. Dense genetic map of tropical maize, constructed with 139 microsatellite markers, based on $256 \mathrm{~F}_{2}$ plants derived from crossing L-02-03D and L-20-01F parental lines. The name of each marker is identified on the right side of each chromosome; on the left are their lengths in centimorgans (cM). Dark circles indicate the estimated centromeric region positions, obtained by Gardiner et al. (1993). The map covered $1,858.61 \mathrm{cM}$ with an average interval of $13.47 \mathrm{cM}$ between markers.

replaced by previous developed information found in the MaizeGDB, procedure previously used by other authors (Sibov et al. 2003; Mangolin et al. 2004).

\section{Discussion}

The absence of amplification for several microsatellites suggests that there might have occurred an annealing failure with the sequence of the temperate maize germplasm. This annealing failure can be due to differences in base sequences of the loci evaluated, between the temperate maize germplasm, for which the primers were designed, and the tropical germplasm under study. Working with Expressed Sequence Tag (EST) library from tropical maize endosperm, and also with EST library from USA and Europe, Verza et al. (2005) used bioinformatic tools (CAP3 software) and observed that the software identified three consensus sequences for each gene. This showed the high polymorphism among tropical maize inbred lines. 
The most frequent sequence motifs found were the dinucleotide $(61 \%)$. These results are aligned with those obtained by Wang et al. (1994) in temperate maize and Sibov et al. (2003) in tropical maize. Chin et al. (1996) analyzing microsatellites available in MaizeGDB and EMBL databases derived from known genes, cDNAs and ESTs of temperate maize, showed that the trinucleotide is the most frequent $(44.5 \%)$ motifs, followed by tetra $(27 \%)$ and di $(15.5 \%)$. The same authors suggested that when microsatellites obtained from non-genic regions are analyzed, the occurrence and characteristic of the motifs can differ.

Results presented by Grupta et al. (1996), which reported that the most abundant microsatellite motif in plants is the (GA)n disagree with those presented in this work, where (AG)n was found to be the most abundant. On the other hand, Levinson \& Gutman (1987) commented that the differences between motifs are partially due to methylation patterns in different species.

Although the dinucleotide motif has shown the best resolution in terms of allele separation, Taramino \& Tingey (1996) observed that in temperate maize, the best resolution and facility to separate using highresolution agarose gel would be tri and tetranucleotide microsatellites motifs, even with a single repetition unit of difference between the alleles. The same authors commented that null alleles could be nucleotide sequence polymorphisms occurring at the primer sites.

Segregation distortion from expected Mendelian segregation ratios of molecular markers have been reported in maize (Bentolila et al. 1992, Gardiner et al. 1993, Murigneux et al. 1993, Pereira \& Lee 1995), as well as in many other plant species. Using IBM and LHRF temperate maize populations of intermated recombinant inbred lines (IRILs), Falque et al. (2005) found high rates of segregation distortion. Sharopova et al. (2002) observed even higher rates (43\%) with 983 loci (mainly SSRs) mapped on IBM, and Lee et al. (2002) and Lu et al. (2002) found also high proportions of distorted loci in nonfixed intermated recombinant inbred lines (RILs) maize populations from B73 X Mo17 and LH200 X LH216 crosses. Xu et al. (1997) found more segregation distortion in RILs than in doubled-haploid, backcross, or $\mathrm{F}_{2}$ rice populations, and $\mathrm{Lu}$ et al. (2002) also stated that segregation distortion accumulates with additional generations of meiosis, which may be explained by the fact that more generations result in a stronger effect of selection. No segregation distortion was observed in any marker used in our work, which is an indication that the molecular marker system was correct, that the type and size of the population ( $\mathrm{F}_{2}$ population) was appropriate, and that no specific biologic event occurred, such as gametic variability differentiation during gametogenesis fertilization or germination. Coe et al. (1995) report that it is not unusual to find loci with a segregation distortion in populations where a high number of markers have been analyzed and the results are probably an artifact of sampling. Gardiner et al. (1993) showed that, in mapping studies with two populations derived from the same maize parental crossing, some regions presented segregation distortion in one population but not in the other.

The microsatellite map position was in accordance, but some alterations in marker positions were observed for chromosomes two, three, four, five and nine, when compared to their locations per bins with the Mangolin et al. (2004) map using the same tropical germplasm. In chromosome two, small modifications occurred: (i) the bnlg1017 marker (bin 2.02) positioned itself before the umc1165 and umc1227 markers (both in bin 2.01) and (ii) between the umc1946 and bnlg1045 markers (both in bin 2.07) there was the positioning of a block of markers from bin 2.08 (bnlg1329, phi127, bnlg1662 and bnlg1721). In chromosome three, there was an inversion between the bnlg1523 (bin 3.03) and bnlg1647 (bin 3.02) markers. In chromosome four, there was an inversion in the position of the bnlg252 (bin 4.06), nc005 (bin 4.05), umc1088 (bin 4.05) markers and the umc1550 (bin 4.03) marker. In chromosome five, there was an inversion between bnlg105 and bnlg1879 markers (both in bin 5.02) and the bnlg1660 (bin 5.03) marker. In chromosome nine, there was an inversion between the markers of bin 9.01 (phi068 and umc1040) with those from bin 9.00 (bnlg1272). All the inversions in the genetic map can be considered small and expected as they vary in relation to only one or two bins. Gardiner et al. (1993) commented on the common occurrence of small inversions when the markers are very close, separated by few centimorgans.

The map length presented in this study is the greatest when compared to the already published tropical maize maps. Analyzing each chromosome individually, the extensions were also greater. Besides that, the map showed the lower average interval between markers $(13.47 \mathrm{cM})$, comparing with the $19.18 \mathrm{cM}$ and $14.00 \mathrm{cM}$ found for Mangolin et al. (2004) and Sibov et al. (2003), respectively. This lower average interval between markers will allow a more precise QTL mapping.

Some regions presented genetic distance values above $50 \mathrm{cM}$ between the markers, which is the case of the telomeric regions of chromosomes one, four and 
seven, which were not possible to saturate, although we managed to reach a satisfying resolution for telomeric region of chromosomes two and 10 , reducing the distance between the markers. In the genetic map of Mangolin et al. (2004), these large distances were found in the telomeric regions of chromosomes two, four and 10. An explanation would be the increase in the recombination level observed in the telomeric regions, which generated great distances, despite the physical region being considered small (Davis et al. 1999).

Dense genetic maps are determinants in QTL mapping and marker-assisted selection programs, contributing towards physical mapping and, ultimately, gene cloning. This work generated a dense genetic map for a $\mathrm{F}_{2}$ population for tropical maize, using microsatellite markers, providing more information about the genome of this species. A complete genetic map, with all the bins covered, still needs to be constructed. A strategy to reach this goal would be the development and use of specific microsatellite, cloned from tropical germplasm maize genome.

Despite the fact that the sequences currently available in MaizeGDB have been originally developed from the temperate maize germplasm, they were efficient in constructing a tropical maize genetic map. This generates an expectation that the complete map will be reached with the use of microsatellites available in the databases, with a more specific emphasis on the regions that are not yet covered. Apart from this, each year a large amount of new sequences are deposited. Together with this, different molecular markers can also be used in the high-density genetic maps.

The results obtained in this work establish the basis for new studies on genetic architecture of tropical maize towards the identification and mapping of QTL allowing its manipulation and use in maize breeding programs.

Acknowledgements - This research was supported by Fundação de Amparo à Pesquisa do Estado de São Paulo (Fapesp - 99/12143-1 and 01/05702-6) and Conselho Nacional de Desenvolvimento Científico e Tecnológico (CNPq - 2003/302653). A.P. Souza and C.L. Souza Jr. were recipients of a research fellowship from CNPq.

\section{References}

AJMONE-MARSAN, P., MONFREDINI, G., LUDWING, W.F., MELCHINGER, A.E., FRANCESCHINI, P., PAGNOTTO, G. \& MOTTO, M. 1995. In an elite cross of maize a major quantitative trait locus controls onefourth of the genetic variation of grain yield. Theoretical and Applied Genetics 90:415-424.
AUSTIN, D.F. \& LEE, M. 1996. Genetic resolution and verification of quantitative trait loci for flowering and plant height with recombinant inbred lines of maize. Genome 39:957-968.

BENTOLILA, S., HARDY, T., GUITTON, C. \& FREYSSINET, G. 1992. Comparative genetic analysis of $\mathrm{F}_{2}$ plants and anther culture derived plants of maize. Genome 35:575-582.

CHIN, E.C.L., SENIOR, M.L., SHU, H. \& SMITH, J.S.C. 1996. Maize simple repetitive DNA sequences: abundance and allele variation. Genome 39:866-873.

COE, E.H., DAVIS, G.L., MCMULLEN, M.D., MUSKET, T. \& POLACCO, M. 1995. Gene list and working maps. Maize Genetics Cooperation News Letter 69:191-192.

CRESTE, S., TULMAN-NETO, A. \& FIGUEIRA, A. 2001. Detection of single sequence repeat polymorphisms in denaturing polyacrylamide sequencing gels by silver staining. Plant Molecular Biology Reporter 19:299306.

DAVIS, G.L., MCMULLEN, M.D., BAYSDORFER, C., MUSKET, T., GRANT, D., STAEBELL, M., XU, G., POLACCO, M., KOSTER, L., HOUCHINS, K., CHAO, S. \& COE, E.H.J. 1999. A maize map standard with sequenced core markers, grass genome reference points, and 932ESTs in a 1736-locus map. Genetics 152:1137-1172.

DEKKERS, J.C.M. \& HOSPITAL, F. 2002. The use of molecular genetics in the improvement of agricultural populations. Nature Genetics 3:22-32.

DON, R.H., COX, P.T., WAINWRIGHT, B.J., BAKER, K. \& MATTICK, J.S. 1991. Touchdown PCR to circumvent spurious priming during gene amplification. Nucleic Acids Research 19:4008-4008.

EDWARDS, M.D., HELENTJARIS, T. \& WRIGHT, S. 1992. Molecular-marker-facilited investigations of quantitative trait loci in maize. 4. Analysis based on genome saturation with isozyme and restriction fragment length polymorphism markers. Theoretical and Applied Genetics 83:765-774.

ELLEGREN, H. 2000. Microsatellite mutations in the germline: implications for evolutionary inference. Trends in Genetics 16:551-558.

FALQUE, M., DÉCOUSSET, L., DERVINS, D., JACOB, A.-M., JOETS, J., MARTINANT, J.-P., RAFFOUX, X., RIBIÈRE, N., RIDEL, C., SAMSON, D., CHARCOSSET, A. \& MURIGNEUX, A. 2005. Linkage mapping of 1454 new maize candidate gene loci. Genetics 170:1957-1966.

GARDINER, J., COE, E.H., MELIA-HANCOCK, S., HOISINGTON, D.A. \& CHAO, S. 1993. Development of a core RFLP map in maize using an imortalized- $\mathrm{F}_{2}$ population. Genetics 134:917-930.

GRUPTA, P.K., BALYAN, H.S., SHARMA, P.C. \& RAMESH, B. 1996. Microsatellites in plants: a new class of molecular markers. Current Science 70:45-54. 
HOISINGTON, D., KHAIRALLAH, M.M. \& GONZÁLEZDE-LÉON, D. 1994. Laboratory Protocols: CIMMYT applied molecular genetics laboratory. $2^{\text {nd }}$ ed., CIMMYT, Mexico.

KOSAMBI, D.D. 1944. The estimation of map distances from recombination values. Annals of Eugenics 12:172-175.

LEE, M., SHAROPOVA, N., BEAVIS, W.D., GRANT, D., KATT, M., BLAIR, D. \& HALLAUER, A. 2002. Expanding the genetic map of maize with the intermated (B73 $\times$ Mo17 IBM) population. Plant Molecular Biology 48:453-461.

LEVINSON, G. \& GUTMAN, G. 1987. A slipped-strand mispairing: a major mechanism for DNA sequence evolution. Molecular Biology and Evolution 4: 203-221.

LINCOLN, S.E., DALY, M.J. \& LANDER, E.S. 1993. Constructing genetic linkage maps with MAPMAKER/ EXP version 3.0b. Whitehead Institute for Biomedical. Research Technical Report, $3^{\text {rd }}$ ed., Cambridge.

LU, H., ROMERO-SEVERSON, J. \& BERNARDO, R. 2002. Chromosomal regions associated with segregation distortion in maize. Theoretical and Applied Genetics 105:622-628.

LYTTLE, T.W. 1991. Segregation distorters. Annual Review Genetic 25:511-557.

MANGOLIN, C.A., SOUZA JR., C.L.A., GARCIA, A.F., GARCIA, A.F., SIBOV, S.T. \& SOUZA, A.P. 2004. Mapping QTL for kernel oil content in a tropical maize population. Euphytica 137:251-259.

MARMUR, J. \& DOTY, P. 1962. Determination of the base composition of deoxyribonucleic acid from its thermal denaturation temperature. Journal of Molecular Biology 5:109-118.

MEKSEM, K., RUBEN, E., HYTEN, D.L., SCHMIDT, M.E. \& LIGHTFOOT, D.A. 2001. High-throughput genotyping for a polymorphism linked to soybean cyst nematode resistance gene rhg4 by using TaqmanTM probes. Molecular Breeding 7:63-71.

MOREAU, L., CHARCOSSET, A., HOSPITAL, F. \& GALLAIS, A. 1998. Marker-assisted selection efficiency in populations of finite size. Genetics 148:1353-1365.

MURIGNEUX, A., BAUD, S. \& BECKERT, M. 1993. Molecular and morphological evaluation of doubledhaploid lines in maize. 2. Comparison with singleseed-descent lines. Theoretical and Applied Genetic 87: 278-287.

PEREIRA, M.G. \& LEE, M. 1995. Identification of genomic regions affecting plant height in sorghum and maize. Theoretical and Applied Genetics 90:380-388.

RIBAULT, J.M., HOISINGTON, D.A., DEUTSCH, J.A., JIANG， C. \& GONZALEZ-DE-LÉON, D. 1996. Identification of quantitative trait loci under drought condition in tropical maize. 1. Flowering parameters and the anthesis-silking interval. Theoretical and Applied Genetics 92:905-914.
RICE, W.R. 1989. Analyzing tables of statistical tests. Evolution 43:223-225.

SAMBROOK, J., FRITSCH, E.F. \& MANIATIS, T. 1989 Molecular cloning: a laboratory manual, $2^{\text {nd }}$ ed. Cold Spring Harbor Laboratory Press, New York, p.B23.

SARGENT, D.J., CLARKE, J., SIMPSON, D.W., TOBUTT, K.R., ARÚS, P., MONFORT, A., VILANOVA, S., DENOYES-ROTHAN, B., ROUSSEAU, M., FOLTA, K.M., BASSIL, N.V. \& BATTEY, N.H. 2006. An enhanced microsatellite map of diploid Fragaria. Theoretical and Applied Genetics 112:1349-1359

SCHLÖTTERER, C. 2004. The evolution of molecular markers - just a matter of fashion? Nature Reviews Genetics 5:63-69.

SERVIN, B. \& HOSPITAL, F. 2002. Optimal positioning of markers to control genetic background in marker assisted backcrossing. Journal of Heredity 93:214-217.

SHAROPOVA, N., MCMULLEN, M.D., SCHULTZ, L., SCHROEDER, S., SANCHEZ-VILLEDA, H., GARDINER, J., BERGSTROM, D., HOUCHINS, K., MELIA-HANCOCK, S., MUSKET, T., DURU, N., POLACCO, M., EDWARDS, K., RUFF, T., REGISTER, J.C., BROUWER, C., THOMPSON, R., VELASCO, R., CHIN, E., LEE, M., WOODMANCLIKEMAN, W., LONG, M.J., LISCUM, E., CONE, K., DAVIS, G. \& COE, E.H. 2002. Development and mapping of SSR markers for maize. Plant Molecular Biology 48:463-481.

SIBOV, T.S., SOUZA JR., C.L., GARCIA, A.A.F., GARCIA, A.F., SILVA, A.R., MANGOLIN, C.A., BENCHIMOL, L.L. \& SOUZA, A.P. 2003. Molecular mapping in tropical maize (Zea mays L.) using microsatellite markers. 1. Map construction and localization of loci showing distorted segregation. Hereditas 139:96106.

TARAMINO, G. \& TINGEY, S. 1996. Simple sequence repeats for germplasm analysis and mapping in maize. Genome 39:277-287.

TRUCO, M.J., ANTONISE, R., LAVELlE, D., OCHOA, O., KOZIK, A., WITSENBOER, H., FORT, S.B., JEUKEN, M.J.W., KESSELI, R.V., LINDHOUT, P., MiCHELMORE, R.W. \& PELEMAN, J. 2007. A high-density, integrated genetic linkage map of lettuce (Lactuca spp.). Theoretical and Applied Genetics 115:735-746.

VARSHNEY, R.K., MARCEL, T.C., RAMSAY, L., RUSSELL, J., RO, M.S., STEIN, N., WAUGH, R., LANGRIDGE, P., NIKS, R.E. \& GRANER, A. 2007. A high density barley microsatellite consensus map with 775 SSR loci. Theoretical and Applied Genetics 114:1091-1103.

VELDBOOM, L.R. \& LEE, M. 1996. Genetic mapping of quantitative trait loci in maize in stress and nonstress environments: I. Grain yield and yield components. Crop Science 36:1310-1319. 
VERZA, N.C., SILVA, T.R, NETO, G.C., NOGUEIRA, F.T.S., FISCH, P.H., ROSA-JÚNIOR, V.E., REBELLO, M.M., VETTORE, A.L., SILVA, F.R. \& ARRUDA, P. 2005. Endosperm-preferred expression of maize genes as revealed by transcriptome-wide analysis of expressed sequence tags. Plant Molecular Biology 59:363-374.

WANG, C.-J.R., HARPER, L. \& CANDE, W.Z. 2006. High-resolution single-copy gene fluorescence in situ hybridization and its use in the construction of a cytogenetic map of maize chromosome 9. The Plant Cell 18:529-544.

WANG, Z., WEBER, J.L., ZHONG, G. \& TANKSLEY, S.D. 1994. Survey of plant short tandem repeats. Theoretical and Applied Genetics 88:1-6.
WEI, F., NELSON, W., GOICOECHEA, J.L., ENGLER, F. \& LEE, S.A. 2004. An integrated genetic and physical map of the maize. Maize Genetics Conference Abstracts 46:125.

XU, Y., ZHU, L., XIAO, J., HUANG, N. \& MCCOUCH, S.R. 1997. Chromosomal regions associated with segregation distortion of molecular markers in $\mathrm{F}_{2}$, backcross, doubledhaploid, and recombinant inbred populations in rice (Oryza sativa L.). Molecular and General Genetics 253:535-545.

YOUNG, N.D. 1999. A cautiously optimistic vision for marker assisted breeding. Molecular Breeding 5:505510. 